\title{
Identifying the Influential Factors in the Change of Residential to Commercial Areas: a Case Study in Rungkut Madya, Surabaya
}

\author{
Raditio Bachtiar, Bambang Soemardiono, and Dewi Septanti \\ Department of ArchitectureInstitut Teknologi Sepuluh Nopember, Surabaya \\ e-mail: raditiobachtiar@gmail.com
}

\begin{abstract}
Abstrak - The development of road transport that increased on Jalan Rungkut madya in a few years has made A positive impact on an area in terms of the economy. However, the negative impact of that development is to make the changing function of land use to be a commercial area that disrupt the function. The changes in the area function unconsciously impact the changes in the city's design elements on which influences the quality of a design of the city. To find out what factors that affect the change of a function area is indispensable in becoming a reference in designing a good commercial area. The paradigm in this study uses the post-positivist paradigm, where this paradigm is a qualitative method that uses a scientific approach, the strategy used is combined strategy between quantitative and case studies. The primary Data used in this study came from observations and questionnaires. The results in this study included identifying influential factors in the change of residential functions into commercial areas.
\end{abstract}

Kata Kunci-Commercial Areas, Land Use Change, PostPositivist, Quantitative.

\section{INTRODUCTION}

$\mathrm{U}$ RBAN area development occurs in networks of social interactions across landscape boundaries and in spatial systems that are not uniform or not simultaneous. The development of a city or region identity is, of course, based on a city government program that seeks to harmonize the physical development of the city and the development of its human resources or labor [1]. The development of a city or region will certainly never be separated from the development of economic activity. This development is an activity carried out by the community to improve the quality of life in a city or region. Of course, from these developments there will be an impact on population growth which will then result in increased demand for land. The very limited availability of land will lead to competition among land users in an area. Thus, resulting in land changes in an urban area.

Changes in the function of an area in urban areas greatly affect the residents of residential areas. Moreover, if the commercial area is in the same area as the residential area, or the residential area that changes its function due to economic factors becoming a commercial area [2]. Changes in the function of the region are also experienced in big cities in Indonesia. The city of Surabaya, which is a rapidly developing city later this year also experienced that change. The growth and development of the city of Surabaya is influenced by various factors, both factors originating from within the city itself (internal) and those from outside (external). These factors are interrelated with one another, thus providing an influence on the dynamics of the city.

Surabaya City Government, lately this year often develops the city by building several road transportation facilities in several regions. It is undeniable that an increase in the construction of road transportation facilities can have a positive impact on the area. Such as increasing the economy of the surrounding residents, waking up, reducing traffic, giving comfort to road users, and so on. However, the negative effects of development are also unavoidable. The unregulated area that experiences the development of transportation facilities and infrastructure changes the function of a region's land use.

There are problems that are specifically directly related to the elements of urban design ranging from functional problems of the region due to uncontrolled land use developments, developments in the city's physical development, violations of building height regulations, violations of building boundaries, multifunctional building issues, lack of green open spaces replaced by the mass of buildings that are so dense and many more problems faced by a city.

Besides having a high population density, Surabaya with its various activities, also experienced a very rapid development of the city. Starting from the facilities and infrastructure that supports the development.

The development of the city finally made one of the regions in Surabaya experience a change in the function of the region. Originally an area with residential land use, now it is a trade area. The change of residential areas to commercial areas which is a problem in this study has trigger factors. There are six important factors in the process of changing the function of occupancy, namely the characteristics of land values, completeness of utility, land accessibility, personal characteristics of land owners, land use regulations and commercial development initiatives [3]. The following is the translation according to the Urban Spatial Structure:

1. Land value characteristics, land value characteristics are economic conditions that take into account land values and land productivity, the higher the land productivity, the higher the land value [4]

2. Completeness of utilities, basically the city center or residential land requires a more complete utility so that it 
The $6^{\text {th }}$ International Seminar on Science and Technology (ISST) 2020

July $25^{\text {th }} 2020$, Institut Teknologi Sepuluh Nopember, Surabaya, Indonesia

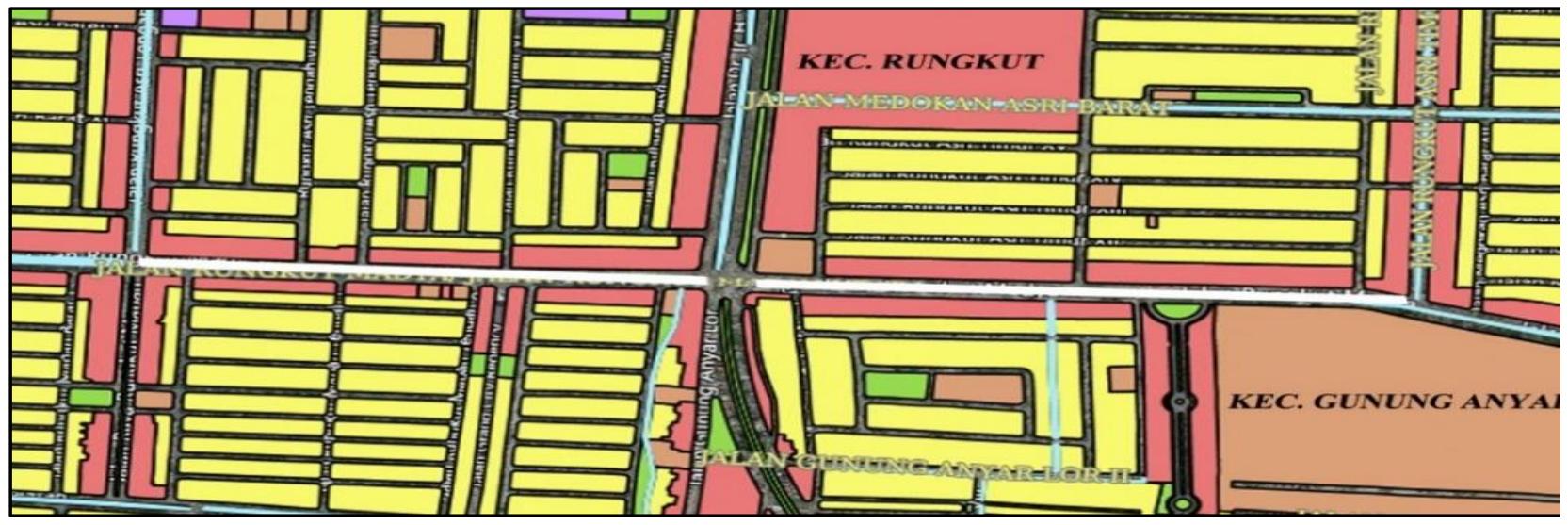

Figure 1. Borderline of location.

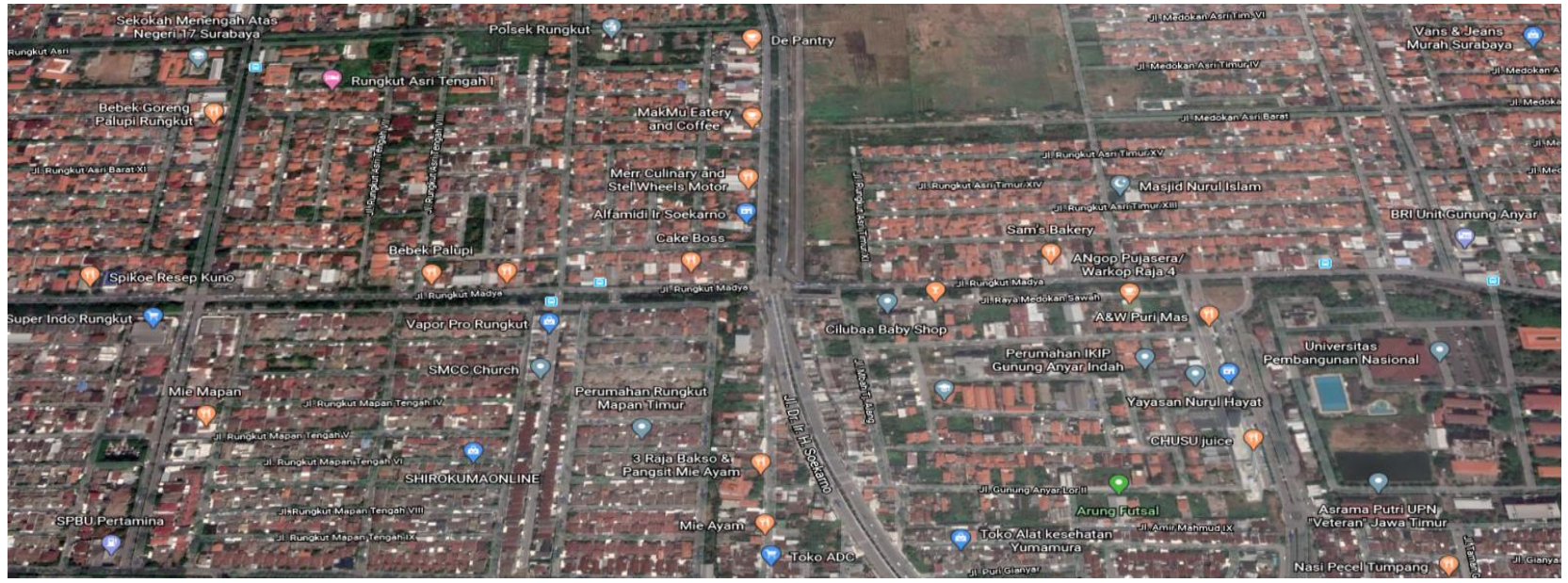

Figure 2. Location of study.

requires greater funding than other locations that are not in the city center or called the central city-suburban fiscal disparities problem.

3. Land accessibility, the higher the accessibility of the land, the higher the profit, the intended accessibility is to attract customers.

4. Owner's personal characteristics, social changes occur when there are changes to the balance of social relationships (social relationships). These social changes are periodic and non periodic that occur due to changes in the balance of geographical, biological, economic elements (income, expenditure and livelihood), social (land status, length of stay, number of family members, age) and culture (religion, customs etc.) [5].

5. Land use regulations, regulations regarding land use are a continuous and consistent effort in directing the use, use and development of land in a direction that is directed, efficient and effective in accordance with the spatial plans that have been determined [6].

6. Commercial development initiatives, talk about land use that cannot be separated from land value, land rent (rent) and costs (costs) by carefully calculating it.

Besides this theory, there is one other supporting theory, namely the theory of urban design. There are 8 (eight) kinds of elements that make up a city (especially the city center), namely land use, building form and mass building, open space, circulation and parking [7]. Based on the research topic, not all the elements above need to be studied.

\section{A. Case study}

Rungkut area where in the Regional Spatial Plan (RTRW) has been designated as an area with centers of settlement, trade and education. Rungkut madya area is an area which includes Gunung Anyar Urban Village, Rungkut Kidul Urban Village, Central Rungkut Urban Village. Geographically, the Rungkut madya Region is located at 7019'7 "S and 112048'0" $\mathrm{E}$, and is at an altitude of $6 \mathrm{~m}$ above sea level. The scope of this research area is the Rungkut madya area which has the following limits and can see Figure 1.

1. North: Village office of Rungkut Tengah

2. East: Rungkut Madya Street

3. Southern: Village office of Gunung Anyar

4. West: Village office of Rungkut Kidul

The location of this research study is in Jalan Rungkut madya Surabaya which is included in the Rungkut subdistrict, Rungkut Kidul sub-district. On this road, it can be seen on the map that the land allotment is as a commercial or trade and service corridor. The length of Jalan Rungkut madya is $1.3 \mathrm{Km}$. Historically, this road was not too crowded with buildings that functioned as trade and services. There are still many buildings that function as residences. However, as a result of the construction of Ring Road in this area, the Madras Rungkut Middle Road became a secondary road with a higher density. Location of study can see Figure 2. 


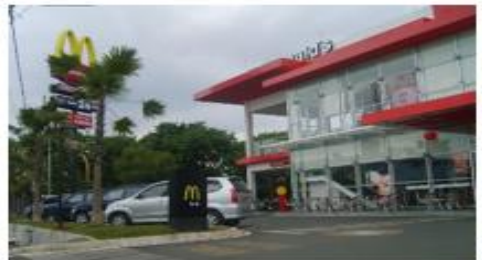

(a)

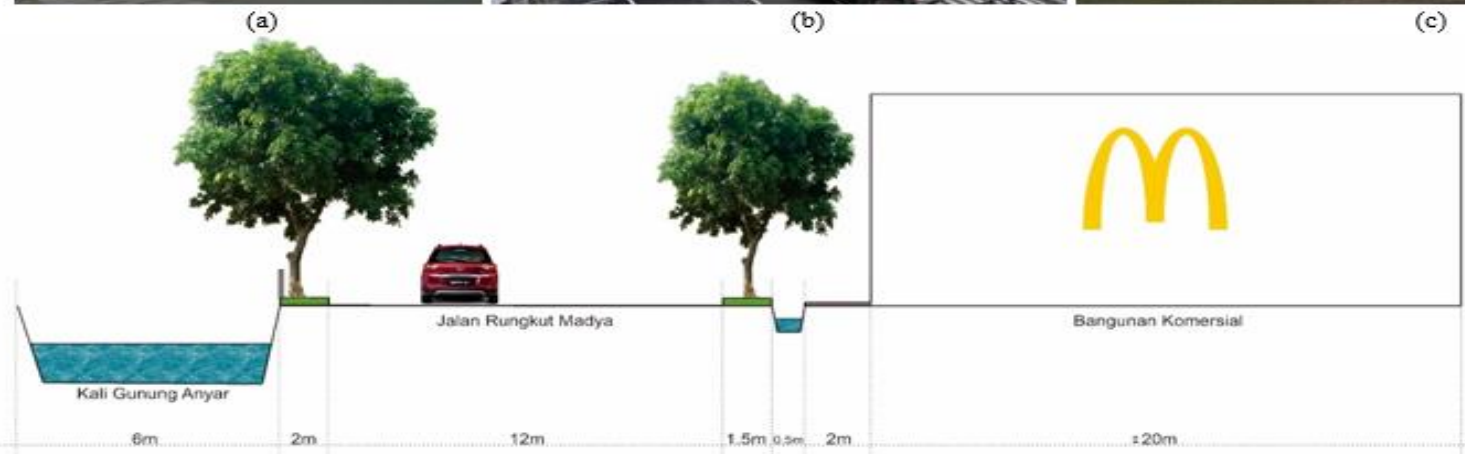

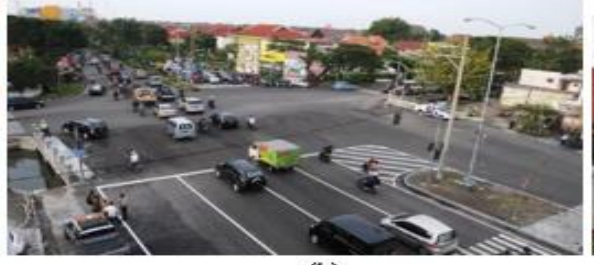

(b)

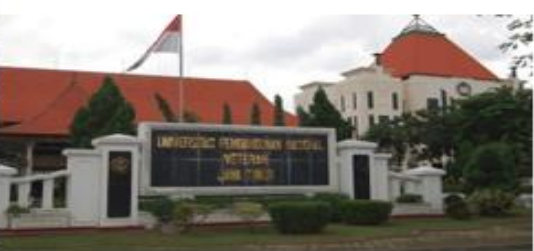

(c)

Figure 3. (a) McDonalds building, (b) MERR, (c) UPN University (d) Section of Rungkut madya.

Table 1.

Variables Data Research

\begin{tabular}{lll}
\hline \hline & \multicolumn{2}{c}{ Variable } \\
\hline Factors Can Affect The Most Of \\
$\begin{array}{ll}\text { Transition Function To A Commercial } \\
\text { Area }\end{array}$ & Completeness of Utility & Clean Water Flow \\
& & Drainage Channel \\
& & Electricity \\
& & Telecommunication / Network Connection \\
\cline { 2 - 3 } & Accessbility & Ring Road \\
\cline { 2 - 3 } & Urban Design Theory & Building form and massing \\
& & Circulation and Parking \\
& & Signage \\
& Pedestrian Ways \\
\hline \hline
\end{tabular}

When viewed from its history in this area, there are several commercial buildings that are landmarks on this road. This landmark appeared not because it was designed as it should, but this landmark emerged as a result of the perception or assumption of residents around the area as a benchmark for residents from other regions who find it difficult to find the Rungkut madya street. The landmarks on this road are McDonald's on the west side, the MERR road on the middle of the segment that separates between segments one and two, and UPN Veteran is the landmark on the east side of this segment and can see Figure 3.

The picture below is the result of observations in the field so that it can easily provide a schematic description of the Rungkut madya road section. This section is drawn so that it can be a reference for researchers in further analysis of the factors on target one.

\section{METHOD}

The methodology in this research uses quantitative research methods and case studies [8]. Data analysis tactics using SPSS and descriptive analysis. Data collection tactics using a questionnaire with Purposive non-probability sampling. This tactic takes respondents as samples based on anyone who happens to be met and is considered capable as respondents [9]. The questionnaire contained research variables between the variables of urban design elements and the triggering variables for the occurrence of commercial areas. The results of the questionnaire were performed data correlations and factor analysis to find the most influential factors in the change of regional functions.

\section{A. Sample Determination}

The sampling of the samples in this study used Purposive non probability sampling with the tactics of Convenience anncidental Random sampling. Sampling is based on the fact that those who go through the street by car with the intensity at least once a week, and based on who is accidentally encountered and considered suitable as a respondent [9].

$$
\begin{gathered}
n=\left[\frac{Z \frac{1}{2} \alpha}{E}\right]^{2} \\
n=\left[\frac{1,96 \cdot 0,25}{E 0,05}\right]^{2}
\end{gathered}
$$

$\mathrm{n} \quad=$ Number of samples

$\mathrm{Z}^{1} \frac{1}{2}=$ Sample Normal Distribution Table- $95 \%$ (Accuracy

level) $=1,96$

$\alpha \quad=$ Sample Error- $25 \%$

$\mathrm{E}=$ Error of Estimate $(5 \%-20 \%)$

In this study a tolerable fault limit was $5 \%$ so that the accuracy level sample was $95 \%$ (1.96). From the calculation 
The $6^{\text {th }}$ International Seminar on Science and Technology (ISST) 2020

July $25^{\text {th }} 2020$, Institut Teknologi Sepuluh Nopember, Surabaya, Indonesia

Table 2.

Validity Test Data

\begin{tabular}{|c|c|c|c|}
\hline Sub-variabel & r-Number & r-table & Result \\
\hline Clean Water Flow & 0,542 & 0,195 & Valid \\
\hline Drainage Channel & 0,406 & 0,195 & Valid \\
\hline Electricity & 0,422 & 0,195 & Valid \\
\hline Telecommunication / Network Connection & 0,390 & 0,195 & Valid \\
\hline Ring Road & 0,369 & 0,195 & Valid \\
\hline Building form and massing & 0,672 & 0,195 & Valid \\
\hline Circulation and Parking & 0,487 & 0,195 & Valid \\
\hline Signage & 0,601 & 0,195 & Valid \\
\hline Pedestrian Ways & 0,418 & 0,195 & Valid \\
\hline Activity Support & 0,465 & 0,195 & Valid \\
\hline
\end{tabular}

Table 3.

Reliability Test Data

\begin{tabular}{lccc}
\hline \hline \multicolumn{1}{c}{ Variable } & Cronbach's alpha (a) & Item Number & Description \\
\hline Causes Factor of Commercial Areas & 0,607 & 5 & Reliabel \\
Urban Design Theory & 0,607 & 5 & Reliabel \\
\hline \hline
\end{tabular}

Table 4.

KMO test and bartlett's Test

\begin{tabular}{llr}
\hline \hline & KMO and Bartlett's Test & $\mathbf{. 6 5 1}$ \\
\hline Kaiser-Meyer-Olkin Measure of Sampling Adequacy. & & 153.418 \\
Bartlett's Test of Sphericity & Approx. Chi-Square & 45 \\
& df & .000 \\
\hline \hline
\end{tabular}

result using the formula, obtained the number of samples to be taken into part of the research is 96.04 (rounded 100 respondents).

\section{RESULT AND DISCUSSION}

The results of this study are based on the data from respondents and the analysis of the factors in the questionnaire that have been distributed to three types of people. Among them are entrepreneurs, residents who are behind the corridor and visitors or road users. Respondent data is used to classify any factors that can influence the change of function of residential areas to commercial.

This section discusses factor analysis by testing the validity of reliability and identifying new factors from several factors that already exist. At this stage it will produce new factors by looking at the highest to the lowest factors according to the results of the questionnaire in the field. The code for each variable is derived from the order in which questionnaire numbers have been distributed to respondents. Following are any naming or coding factors from the results of data analysis using SPSS. Variabless data research can see Table 1.

The next step is the validity test. Validity test is the level of expertise of the measuring instrument used. The instrument can be said to be valid if it shows the measuring instrument used to obtain valid data [9]. Product Moment Person correlation is a test tactic used in this validity test. The results of $r$ arithmetic on each variable will be compared with the value of $r$ table with a level of $5 \%$ if the $r$ count is more than $r$ tables, then the variable is declared true or valid and can proceed to the next test stage. The following are the results of the validity test.

Based on table 2, it can be seen that all sub-variables on this questionnaire are declared valid. This is because all the values in the r-count are greater than the r-table value of
0.195 . With valid results this data can proceed to the next stage. At this stage a reliability test will be used to determine whether the questionnaire can be used more than once, with the same respondent data will produce consistent data.

The reliability test sees the value of Cronbach's alpha (a) of 0.6 if the value of Cronbach's alpha (a) exceeds or equals 0.6 then the statements are consistent and relevant to the variable. Here is the reliability test table and can see Table 3.

This step is determining the amount of the Kaiser-MayerOlkin (KMO) Measure of Sampling adequancy. The magnitude of the KMO value is used to measure the adequacy of the sample by comparing it with the observed correlation coefficient with its partial correlation coefficient. The following is the result of data analysis and can see Table 4.

From these results the KMO-MSA value obtained was 0.651 , the figure was above the threshold value of 0.5 . While the significance of 0,000 which explains that the forming factors of this variable are good and can be continued at a later stage.

At this step the number of factors formed can be known by Total Variance Expalined by looking at the Initial Eigenvalues column. In the table the number of factors formed is 10 Common factors. The following data on the results of the Total Variance Expalined test can be seen Table 5.

From the results of these data formed as many as 4 factors. These factors are formed because they have an Initial Eigvalues value of more than 1.00. Eigenvalues below 1 cannot be used in calculating the number of factors formed. With a cumulative percentage of 63.724 of these numbers will explain $63.724 \%$ of the variability of all of the original variables. The process of determining these variables belongs to a group of factors which will be determined by the magnitude of the correlation value on each row. If in a variable has almost the same correlation value, it is necessary 
The $6^{\text {th }}$ International Seminar on Science and Technology (ISST) 2020

July $25^{\text {th }} 2020$, Institut Teknologi Sepuluh Nopember, Surabaya, Indonesia

Table 5.

Total Variance Expalined Analysis

\begin{tabular}{lrrrrrr}
\hline \hline & \multicolumn{3}{c}{ Total Variance Explained } \\
\hline & \multicolumn{5}{c}{ Initial Eigenvalues } & \multicolumn{2}{c}{ Extraction Sums of Squared Loadings } \\
\cline { 2 - 7 } Component & Total & \% of Variance & Cumulative \% & Total & \% of Variance & Cumulative \% \\
\hline 1 & 2.424 & 24.240 & 24.240 & 2.424 & 24.240 & 24.240 \\
2 & 1.769 & 17.689 & 41.929 & 1.769 & 17.689 & 4.929 \\
3 & 1.156 & 11.563 & 53.492 & 1.156 & 11.563 & 5.237 \\
4 & 1.024 & 10.237 & 63.729 & 1.024 & \\
5 & .839 & 8.389 & 72.117 & & \\
6 & .712 & 7.116 & 79.234 & & \\
7 & .631 & 6.313 & 85.547 & & \\
8 & .604 & 6.045 & 91.591 & & \\
9 & .468 & 4.683 & 96.275 & & \\
10 & .373 & 3.725 & 100.000 & & \\
\hline \hline
\end{tabular}

Table 6.

Rolated Component Matrix Analysis Rolated Component Matrix ${ }^{\mathrm{a}}$

Clean Water Flow

Drainage Channel

Electricity

Telecommunication / Network Connection

Ring Road

Building form and massing

Circulation and Parking

Signage

Pedestrian Ways

Activity Support

\begin{tabular}{rrrrrr}
\multicolumn{5}{c}{ Component } \\
\hline $\mathbf{1}$ & & $\mathbf{2}$ & $\mathbf{3}$ & $\mathbf{4}$ \\
\hline & .648 & & .337 & .023 & -.127 \\
.570 & .288 & -.398 & -.089 \\
.742 & -.047 & .001 & .166 \\
.667 & -.050 & .106 & .041 \\
.508 & -.195 & .413 & .310 \\
.075 & .863 & .076 & .081 \\
.095 & .177 & .793 & .087 \\
.029 & .799 & .105 & .129 \\
.056 & .249 & .081 & .879 \\
-.094 & .450 & .545 & -.429 \\
\hline
\end{tabular}

Table 7 .

Naming analysis factors

\begin{tabular}{lc}
\hline \hline \multicolumn{1}{c}{ Nama Sub-Variabel } & New Factors Name \\
\hline Electricity & Utility Supply Factor \\
Telecommunication / Network Connection & \\
Clean Water Flow & \\
Drainage Channel & \\
Ring Road & Visual Factor \\
\hline Building form and massing & Support Factor \\
Signage & Streetscape Factor \\
\hline Circulation and Parking &
\end{tabular}

to do a factor rotation step in the next analysis so that each variable does not have nearly the same value.

At this stage the results of the Component Matrix on the results of the research questionnaire can be considered through its component factors, if the value is $>0.5$ then the sub-variable is a member of the formed factor. After 4 factors are formed optimally, it can be selected in the Component Matrix which shows the distribution of the 10 remaining variables in the 4 factors formed and can see Table 6 .

But the results of the rotated component matrix data indicate that there is a factor component value $>0.5$ and some have a value $<0.5$ in the sub-variable this indicates that the data cannot be rotated again so that the data is interpreted as is as in previous analysis results.

Following is the result of grouping the factors in the previous stage, the largest value in the sub-variable indicates that the sub-variable belongs to the group of columns and can see Table 7 . The results of the table 7 can be concluded that the 10 existing variables can be grouped into 4 new variables, the grouping of these variables is formed because of the identical characteristics of identical data between one variable with another variable.

\section{CONCLUSION}

The most influential factors in the change of residential to commercial areas is utility supply factor which consisting of the availability of electricity, clean water from the PDAM Surabaya, the availability of telecommunications networks such as the internet, drainage system that are functioning properly, and finally the ring road that facilitates the accessibility of the people from Sidoarjo and East Surabaya to around Surabaya City. Second is visual factors, which consist of the shape and mass of buildings and signage. Third is supporting factors, which consist of circulation, parking area and activity support. Last is the streetscape factor, all things related to pedestrian ways and street furniture.

\section{ACKNOWLEDGEMENT}

This paper is the part of thesis study at master degree of 
The $6^{\text {th }}$ International Seminar on Science and Technology (ISST) 2020

July $25^{\text {th }} 2020$, Institut Teknologi Sepuluh Nopember, Surabaya, Indonesia

urban design architectture ITS Surabaya. We would thanks to all respondent and head of village office of Rungkut Kidul. Neighbourhood leader which helped us to conduct this research at Rungkut Asri Timur as the part of Rungkut Madya areas.

\section{REFERENCES}

[1] Garnham, N. 2005. A Personal Intellectual Memoir. Media, Culture \& Society, 27, 469-493.

[2] Bintoro, T. 1984. Pengantar Administrasi Pembangunan Jakarta, LP3ES.
[3] Yunus, H. S. 1999. Struktur tata ruang kota, Pustaka Pelajar.

[4] Sim, L. L. 1984. A Study of Planned Shopping Centres in Singapore, Singapore University Press.

[5] Syahrir. 2010. Kajian Perubahan Pemanfaatan Lahan Perumahan Menjadi Perdagangan Dan Jasa Komersial Di Perumahan Tumbuh I Dan Perumahan Tumbuh II Kota Kendari. Magister Teknik, Universitas Diponegoro.

[6] Jayadinata, J. T. 1992. Tata guna tanah dalam perencanaan pedesaan, perkotaan, dan wilayah, ITB.

[7] Shirvani, H. (1985) Urban Design Process.

[8] Linda N Groat; David Wang (2013) Architectural research methods [electronic resource].

[9] Sugiyono. 2008. Metode penelitian pendidikan: (pendekatan kuantitatif, kualitatif dan R \& D), Alfabeta. 